De gedachte is dat een dialoog wellicht meer herhalingen en verschillende versies van de boodschap bevat en uitleg bij potentieel ingewikkelde passages. Ook kan het verhaal enigszins van twee verschillende kanten worden beluisterd. Daartegenover staat dat de hoofdboodschap bij een dialoog is toegesneden op één specifieke luisteraar, terwijl de "overhearers" maar moeten zien of ze de boodschap oppikken. Ook wordt de spreker mogelijk in het betoog onderbroken en bestaat het risico van zijpaden.

Het experiment betrof de uitleg over een zestiental verschillende tangram-figuren. De spreker probeert deze puzzelfiguren (mensen- of dierenfiguren) achtereenvolgens zo te beschrijven dat de luisteraar ze in volgorde kon plaatsen. In de ene conditie gaf de spreker de beschrijving in de vorm van een monoloog, in de andere conditie was er een "participerende luisteraar", die vragen kon stellen. De audiobanden met deze teksten waren in beide condities even lang. De proefpersonen, 160 studenten van de University of California, kregen steeds banden met zowel dialoog als monoloog te horen (respectievelijk dieren- of mensenfiguren in een counterbalanced onderzoeksdesign).

Het bleek dat een dialoog tot betere prestaties leidde dan een monoloog, zelfs bij diegenen die het luisteren naar de dialogen als minder prettig ervoeren. In een nadere analyse werd uitgesloten dat het aantal woorden, het aantal betekenisloze woorden (um, uh), de spreeksnelheid en zelfs het aantal herhalingen ("conceptual repetitions") van invloed waren. Alleen het aantal "discourse markers", betekenisvolle tussenwerpsels zoals "well, you know, I mean, oh", bleek groter in de dialogen en mogelijk verklarend voor het gevonden effect.

Voor onderwijs is de les wellicht dat luisteren naar dialogen (tussen docenten, tussen studenten, tussen docent en student) wel eens effectiever zou kunnen zijn dan het luisteren naar een klassiek hoorcollege.

Th.J. ten Cate, Utrecht.

\section{Wat leren studenten in de polikliniek?}

Lawrence SL, Lindemann JC, Gothieb W. What stidents value learning outcomes in a required thirdyear ambulatory primary care clerkship. Acad $\mathrm{Med}$ $1999746) 715-7$

De afgelopen jaren is er (met name in het buitenland) een verschuiving herkenbaar van onderwijs in de kliniek naar onderwijs in de polikliniek. De auteurs van het hier besproken artikel definieerden - op basis van eerder verricht onderzoek zeven leersituaties in de polikliniek, zoals "met de patiënt in de onderzoeksruimte", "alleen met de begeleider", "statussen schrijven". Zij hebben de studenten gevraagd aan te geven wat ze van het geleerde in elk van de zeven leersituaties het meest waardevol vonden. Anamnese afnemen en een patiënt onderzoeken werd het vaakst genoemd. Situaties waarin de studenten actief betrokken zijn, werden meer gewaardeerd dan alleen meekijken. Voor veel lezers een logisch resultaat, maar de praktijk is anders en bovendien is het nog niet zo vaak onderzocht én opgeschreven.

A.J.J.A. Scherpbier, Maastricht. 